\title{
Article \\ Effect of Peatland Siltation on Total and Labile C, N, P and K
}

\author{
Slawomir Smolczynski, Barbara Kalisz *D, Pawel Urbanowicz and Miroslaw Orzechowski
}

check for

updates

Citation: Smolczynski, S.; Kalisz, B.; Urbanowicz, P.; Orzechowski, M. Effect of Peatland Siltation on Total and Labile C, N, P and K.

Sustainability 2021, 13, 8240. https:// doi.org/10.3390/su13158240

Academic Editor: Jeroen Meersmans

Received: 7 June 2021

Accepted: 20 July 2021

Published: 23 July 2021

Publisher's Note: MDPI stays neutral with regard to jurisdictional claims in published maps and institutional affiliations.

Copyright: (c) 2021 by the authors. Licensee MDPI, Basel, Switzerland. This article is an open access article distributed under the terms and conditions of the Creative Commons Attribution (CC BY) license (https:// creativecommons.org/licenses/by/ $4.0 /)$.
Faculty of Agriculture and Forestry, University of Warmia and Mazury in Olsztyn, 10-245 Olsztyn, Poland; slawomir.smolczynski@uwm.edu.pl (S.S.); makler128@gmail.com (P.U.); miroslaw.orzechowski@uwm.edu.pl (M.O.)

* Correspondence: barbara.kalisz@uwm.edu.pl

\begin{abstract}
Large areas of peatlands, in addition to the effect of drainage, were subjected to erosional process and were silted. The objective of the study was to verify whether siltation of peatlands hampers mineralization of remaining peat and alters labile $\mathrm{C}, \mathrm{N}, \mathrm{P}$ and $\mathrm{K}$. Total $\mathrm{C}$ and $\mathrm{N}$ were measured on a $\mathrm{CN}$ analyzer, and total $\mathrm{P}$ and $\mathrm{K}$ on an ICP spectrometer after microwave digestion. The labile fractions of $\mathrm{C}, \mathrm{N}, \mathrm{P}$ and $\mathrm{K}$ were extracted with hot water and measured on the $\mathrm{CN}$ analyzer and ICP spectrometer. We noted that labile C, N, P and K concentrations in silted topsoil were lower than the values reported in unsilted topsoil. Higher concentration of labile compounds in peats is a signal of higher biological activity and mineralization of organic matter. A TOC $/ \mathrm{TP}<300$ and TOC/TN of approximately 8 in topsoil suggested diminished mineralization and supported our hypothesis that siltation hampered mineralization of organic matter. The TOC/TK ratio proved to be a fine indicator of the state of organic soils siltation, which enabled the separation of unsilted peats from silted topsoil (on the base of value of 177). It can be assumed that the mineralization of peat layers is hampered by the above lying silted topsoil, which is less biologically active, having less oxygen, and therefore conserving underlying peats against oxidation.
\end{abstract}

Keywords: drainage; water-extractable carbon; peat organic matter

\section{Introduction}

Soil organic matter (SOM) is a mixture of various organic compounds with a diversified susceptibility to decomposition and microbiological transformations. For these reasons, the assessment of SOM quality requires the assessment of labile and/or stable organic matter pools [1,2]. The labile fraction is regarded as an indicator of soil productivity and quality and an important energy source for soil microorganisms [3-5]. It plays important role in soils, especially in the biogeochemistry of carbon, nitrogen and phosphorus [6] and can be a very useful indicator of some nutrient cycles as well as a sensitive indicator of changes in the soil environment $[7,8]$. Land use practices affect the release of labile organic compounds from soil and change the composition of SOM [9]. Still, little is known about whether labile carbon, nitrogen, phosphorous and potassium compounds have an equal response to these processes. Labile organic matter is a source of energy and organic nutrient forms, such as $\mathrm{N}$ and $\mathrm{P}$ readily accessible for soil microbiota $[10,11]$. Although the labile organic fraction constitutes a small proportion of SOM, it is one of the most mobile and bioavailable forms $[8,12-15]$ and can indicate processes that control SOM accumulation and stabilization $[16,17]$.

An important source of labile organic compounds in aquatic ecosystems are peatlands $[18,19]$. Although they cover only 3\% of the Earth's land surface, they contain from $15 \%$ to $30 \%$ of the total carbon stock contained in the world's soils $[20,21]$. Peatlands have been drained by humans for hundreds of years to gain material to heat their homes or to gain fertile land for agricultural or horticultural production. Draining the soil in order to make it suitable for agricultural production leads to physico-chemical changes of peat, decomposition of plant material and transformation of soil organic compounds 
during the mursh-forming process [3,22-25]. During the decomposition of organic material, nutrients are transformed into mobile forms, which can be easily leached and contaminate the ecosystem or can become a source of GHGs in the atmosphere.

Large areas of peatlands located in mid-moraine depressions in young glacial landscapes, in addition to the effect of drainage, were subjected to erosional process (mainly water erosion) occurring on adjacent slopes (Figure 1). The process of covering peatlands or other reservoirs with fine-textured material that eroded from the slope is termed siltation [26-31]. This erosive deposit, called colluvium, may be a preserving medium for buried materials. Over one hundred years ago in Germany, the farmers were covering the peatlands with sand (the Rimpau method) to reduce the overdrying of surface layers of peatland, and consequently reduced oxidation of peat organic matter. Siltation occurring on the peatlands located near the slopes may have a similar effect.

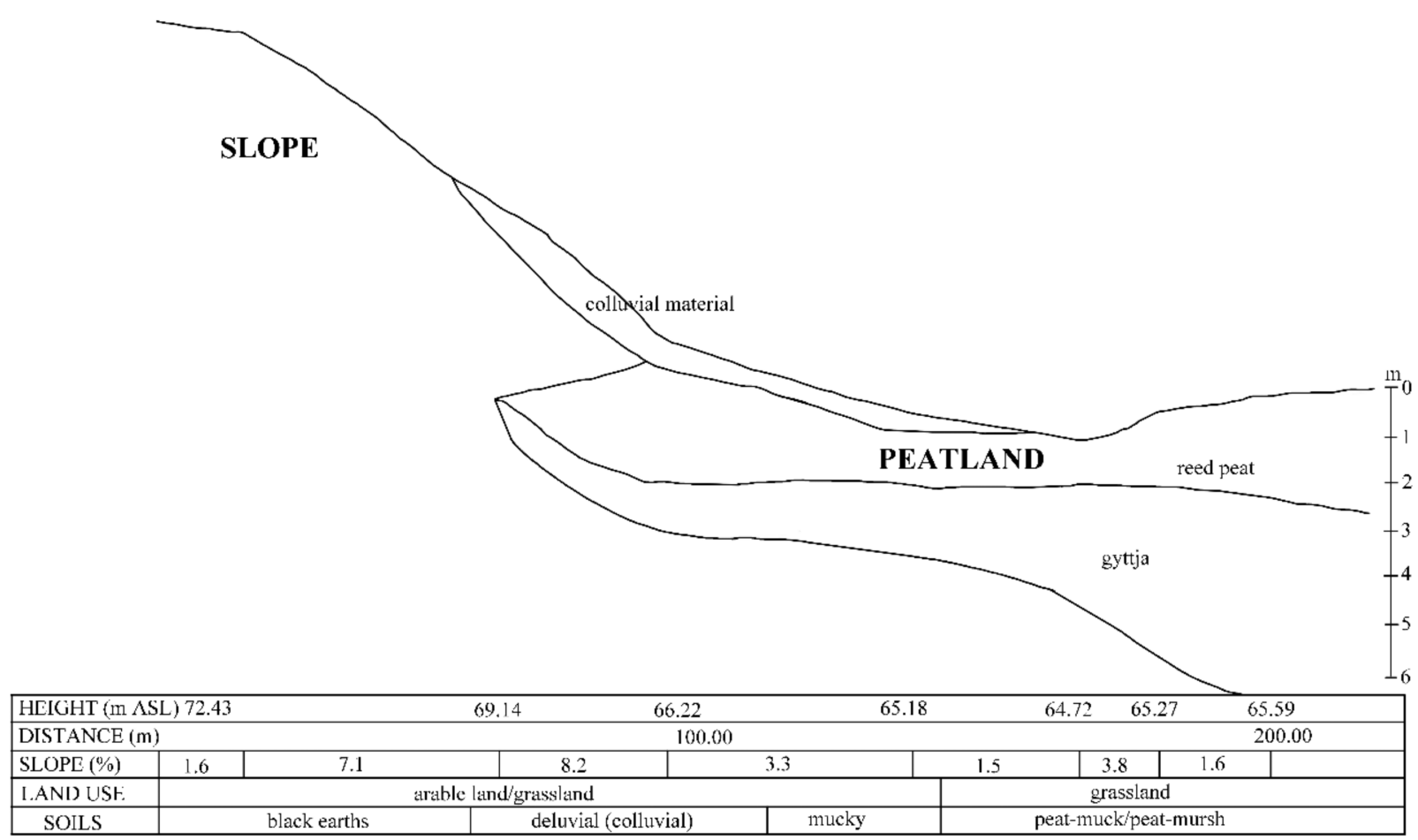

Figure 1. Scheme of siltation of post-lacustrine peatland located in mid-moraine depression.

Zakharova et al. [32] reported that the sanding of peat soils had some positive effect, i.e., improved soil physical properties. From an environmental point of view, Zaidel'man et al. [33] reported that sand application increases the loss of peat organic matter via $\mathrm{CO}_{2}$ emission from the soil surface to the atmosphere. However, the mentioned studies are related to the effect of sand application and do not consider fine-textured materials, which may have a different effect on soil organic matter changes. The main objective of the study was to verify the hypothesis that siltation of peatlands hampers the mineralization of remaining peat layers and alters dissolved $\mathrm{C}, \mathrm{N}, \mathrm{P}$ and $\mathrm{K}$. We verified this hypothesis by (1) analyzing the total and dissolved/labile forms of C, N, P and K in the topsoil and underlying drained peats and (2) analyzing the indicators of organic matter transformations: TOC/TN and TOC/TP.

\section{Materials and Methods}

The soil samples $(n=34)$ were taken from topsoil $(0-30 \mathrm{~cm} ; n=20)$ and subsoil (30-60 cm; $n=14)$ from the peatlands adjacent to the slopes and subjected to siltation in northeastern Poland (Figure 2; geographical coordinates of the study sites: $54^{\circ} 03^{\prime} 27^{\prime \prime} \mathrm{N}$ $21^{\circ} 03^{\prime} 48^{\prime \prime} \mathrm{E}, 54^{\circ} 00^{\prime} 51^{\prime \prime} \mathrm{N} 20^{\circ} 51^{\prime} 19^{\prime \prime} \mathrm{E}, 53^{\circ} 42^{\prime} 56^{\prime \prime} \mathrm{N} 21^{\circ} 19^{\prime} 02^{\prime \prime} \mathrm{E}, 53^{\circ} 38^{\prime} 52^{\prime \prime} \mathrm{N} 20^{\circ} 57^{\prime} 39^{\prime \prime} \mathrm{E}$, 
$54^{\circ} 01^{\prime} 42^{\prime \prime} \mathrm{N} 20^{\circ} 24^{\prime} 23^{\prime \prime} \mathrm{E}$ ) in the years 2017-2019. The climate of this part of Poland is moderate continental-maritime, with an average annual air temperature of about $7.5-8.0^{\circ} \mathrm{C}$ and average annual rainfall from 550 to $650 \mathrm{~mm}$.

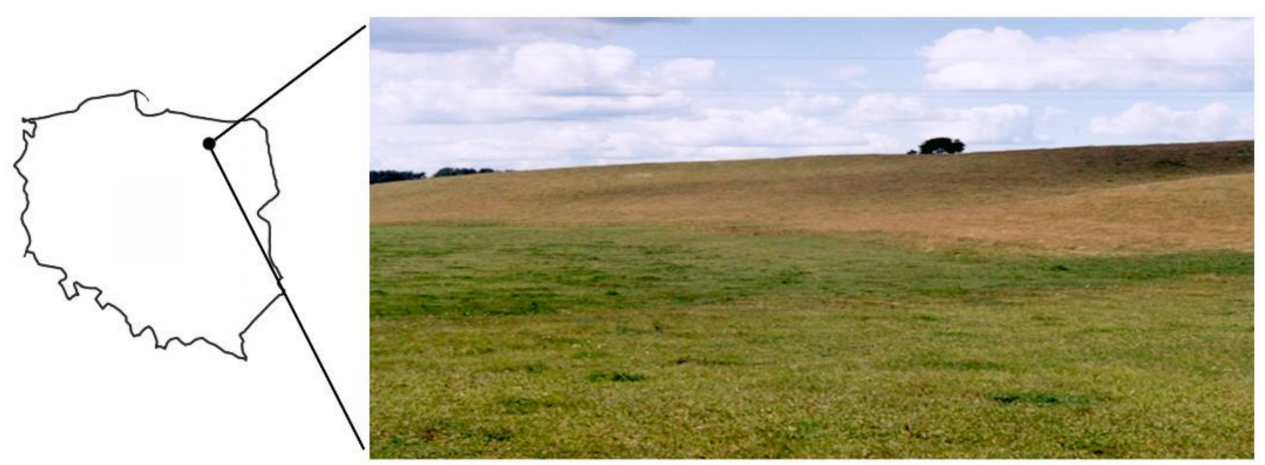

Figure 2. Location of study sites and photo of one of the studied peatlands adjacent to the slope.

The studied peatlands had been formed from reed peats, with a von Post degree of decomposition between $\mathrm{H} 5$ and H7. In the 20th century, the peatlands were drained for agricultural purposes and were subjected to siltation as a result of erosional process occurring at adjacent slopes. Nowadays, the studied sites are used as grasslands. The soils occurring at the studied sites were classified as Hemic, Murshic, Eutric Histosols (Siltinovic) and Hemic, Murshic, Eutric Histosols (according to WRB 2016). Basic soil properties were described in the papers of Smólczyński and Orzechowski [34,35].

SOM was determined on the base of loss-on-ignition at $550{ }^{\circ} \mathrm{C}$; total organic carbon (TOC) and nitrogen (TN) were measured on a Vario MaxCube CN Elementar analyzer. The total phosphorous (TP) and potassium (TK) were measured on an iCAP 7400 ICP-OES Thermo Scientific spectrometer after microwave mineralization (Ultrawave Milestone) in $65 \% \mathrm{HNO}_{3}$. The labile fractions of $\mathrm{C}, \mathrm{N}, \mathrm{P}$ and $\mathrm{K}$ were extracted with hot water according to the method described by Sparling [3]. Briefly, $0.4 \mathrm{~g}$ of air-dried soil was incubated with $20 \mathrm{~mL}$ demineralized water in a capped test-tube at $70^{\circ} \mathrm{C}$ for $18 \mathrm{~h}$. The tubes were shaken by hand at the end of the incubation and then filtered through Whatman ME 25/21 ST $0.45 \mu \mathrm{m}$ membrane filters (mixed cellulose ester). The hot-water soluble C and N (HWC and HWN) were measured on a Multi N/C 3100 Analityk Jena analyzer. The hot-water soluble $\mathrm{P}$ and K (HWP and HWK) were measured on an iCAP Duo 7400 ICP-OES Thermo Scientific spectrometer. All statistical analyses were performed using STATISTICA 13. The influence of state of siltation and depth of soil samples on total and labile C, N, P and K amounts were analyzed by ANOVA. Pearson correlations were used to determine correlation coefficients between variables. On the basis of classification diagrams, we attempted to provide the quantitative criteria that enable the separation of relatively unchanged peats from highly altered topsoil formations.

\section{Results}

The topsoil murshes contained $40.5 \%$ of organic matter on average, with medium variability among the samples, while the colluvium contained the least amount of organic matter, less than $19 \%$, with little variability among the analyzed samples (Table 1). The underlying drained peats (subsoil) contained $76 \%$ of organic matter on average, with a low coefficient of variation. The quantities of TOC and TN were the highest in peats (308.61-459.33 $\mathrm{g} \mathrm{kg}^{-1}$ and $16.64-28.81 \mathrm{~g} \mathrm{~kg}^{-1}$, respectively) and the lowest in colluvium (48.37-117.17 $\mathrm{g} \mathrm{kg}^{-1}$ and $5.20-11.55 \mathrm{~g} \mathrm{~kg}^{-1}$, respectively), with medium or little variability among the samples (Table 1, Table S1). In turn, the contents of total potassium and phosphorus were lower in peats than in topsoil murshes or colluvium. In colluvium TP and TK amounted to $1.3 \mathrm{~g} \mathrm{~kg}^{-1}$ and $5.1 \mathrm{~g} \mathrm{~kg}^{-1}$ on average, respectively. In murshes, the TP values $\left(0.96-1.64 \mathrm{~g} \mathrm{~kg}^{-1}\right)$ were very similar to those obtained for colluvium $\left(0.51-4.64 \mathrm{~g} \mathrm{~kg}^{-1}\right)$, but the TK values were lower $\left(1.22-6.63 \mathrm{~g} \mathrm{~kg}^{-1}\right.$ in murshes and $1.47-10.72 \mathrm{~g} \mathrm{~kg}^{-1}$ in collu- 
vium). In peats, the TP content $\left(0.15-1.32 \mathrm{~g} \mathrm{~kg}^{-1}\right)$ was half of the average value obtained for colluvium or murshes, and TK content $\left(0.21-1.06 \mathrm{~g} \mathrm{~kg}^{-1}\right)$ was 10 times lower (Table 1 , Table S1).

Table 1. Average concentrations of nutrients (in $\mathrm{g} \mathrm{kg}^{-1}$ ) in topsoil and subsoil samples of silted peatland (values in brackets are the coefficient of variation).

\begin{tabular}{cccccccccc}
\hline Soil Sample & OM & TN & TOC & TP & TK & HWC & HWN & HWP & HWK \\
\hline Colluvium & $187.0(24.4)$ & $7.9(30.4)$ & $77.2(29.0)$ & $1.3(89.9)$ & $5.1(60.5)$ & $0.9(35.9)$ & $0.2(64.0)$ & $0.002(65.8)$ & $0.009(96.8)$ \\
Mursh & $405.2(30.8)$ & $16.2(18.0)$ & $201.4(31.2)$ & $1.2(23.2)$ & $3.9(49.9)$ & $1.8(43.2)$ & $0.2(47.5)$ & $0.003(60.3)$ & $0.010(68.2)$ \\
Peat & $760.3(17.9)$ & $22.3(18.7)$ & $391.9(13.9)$ & $0.6(64.6)$ & $0.5(60.0)$ & $5.1(62.9)$ & $0.7(83.7)$ & $0.008(129.5)$ & $0.024(79.9)$ \\
\hline
\end{tabular}

Note: OM—organic matter; TN—total nitrogen; TOC—total organic carbon; TP—total phosphorous; TK—total potassium; HWC—hot water-extractable carbon; HWN—hot water-extractable nitrogen; HWP—hot water-extractable phosphorous; HWK-hot water-extractable potassium.

The concentration of $C$ in hot water extracts was low $\left(0.9-5.1 \mathrm{~g} \mathrm{~kg}^{-1}\right.$ on average; Table 1) and was correlated with TOC (Table 2). In colluvium, the HWC concentration was the lowest; in murshes, it was 2 times higher, and in peats it was 5 times higher than in colluvium (Table 1). In topsoil murshes and colluvium, the variability of the obtained results was medium, and in peats it was high (CV 62.9\%). The HWC concentrations in peats ranged between 1.68 and $12.59 \mathrm{~g} \mathrm{~kg}^{-1}$ (Table S1). It is also worth noting that the values of HWC constitute a very small proportion of TOC, especially in murshes, where they oscillated between $0.4 \%$ and $1.4 \%$. In colluvium, HWC amounted to $0.4-2.4 \%$ of TOC and in peats up to $2.78 \%$ of TOC (Figure 3 ).

Table 2. Correlation coefficients between total and labile forms of C, N, P and $\mathrm{K}$.

\begin{tabular}{cccccccc}
\hline Parameter & TN & TOC & TP & TK & TOC/TN & TOC/TP & TOC/TK \\
\hline HWC & $0.438^{* *}$ & $0.766^{*}$ & -0.380 & $-0.562^{*}$ & $0.772^{*}$ & $0.615^{*}$ & $0.857^{*}$ \\
HWN & 0.246 & $0.627^{*}$ & -0.339 & $-0.477^{* *}$ & $0.816^{*}$ & $0.712^{*}$ & $0.830^{*}$ \\
HWP & $0.571^{*}$ & 0.335 & -0.133 & -0.233 & 0.083 & 0.126 & 0.037 \\
HWK & $0.442^{* *}$ & $0.574^{*}$ & -0.364 & -0.416 & 0.339 & 0.299 & $0.474^{* *}$ \\
HWC/HWN & 0.213 & 0.118 & -0.118 & 0.084 & -0.136 & -0.086 & -0.080 \\
HWC/HWP & 0.124 & $0.478^{* *}$ & -0.339 & -0.389 & $0.706^{*}$ & $0.516^{* *}$ & $0.691^{*}$ \\
HWC/HWK & -0.351 & -0.299 & $0.668^{*}$ & -0.006 & -0.121 & -0.150 & -0.134 \\
\hline
\end{tabular}

Note: OM—organic matter; TN—total nitrogen; TOC—-total organic carbon; TP—total phosphorous; TK—total potassium; HWC—hot water-extractable carbon; HWN—hot water-extractable nitrogen; HWP—hot water-extractable phosphorous; HWK-hot water-extractable potassium; * significant at $p<0.001,{ }^{* *}$ significant at $p<0.01$.

The concentration of HWN was also low, with the lowest amounts in colluvium or murshes (both topsoil formations had similar average HWN concentrations) and the highest in peats (Table 1). HWN was correlated with TOC but not with TN (Table 2). The variability of the results was high in all three groups of soil formations ( $\mathrm{CV}>45 \%)$. In some colluvic, mursh and peat samples, the HWN concentration accounted for a considerable part of total nitrogen (Figure 3). Similarly, the concentrations of $\mathrm{P}$ and $\mathrm{K}$ in hot water extracts were low but not correlated with total amounts of these compounds (Table 2). Noteworthy is the proportion of HWP and HWK in relation to the total quantities of these compounds in peat samples (Figure 3), where they were considerably higher than in topsoil.

The calculated ratios shown in Figure $4 \mathrm{a}-\mathrm{c}$ show some differences between the studied soil formations. The values of TOC/TN ratios were higher in peats $(5-26 ; 18.48$ on average) than in topsoil (8-15; 11 on average), whereas the HWC/HWN ratios remained at a similar level in peats, murshes and colluvium (9-11 on average) but oscillated within wide ranges in all studied soil formations (4-24). It was notable that the values of $\mathrm{HWC} / \mathrm{HWN}$ were, on average, lower than TOC/TN. The values of TOC/TP and HWC/HWP were distinctively higher in peats than in topsoil. It should be noted, however, that in contrast to the $\mathrm{C} / \mathrm{N}$ ratios, the $\mathrm{HWC} / \mathrm{HWP}$ ratios (501-1519) were much wider than the TOC/TP ratios (81-1214). The ratios of TOC/TK were also wider in peats (1100) than in topsoil (19-74). 
However, the relationship in the labile fraction was the opposite, and the HWC/HWK ratios were wider in topsoil (896-259) than in underlying peats.

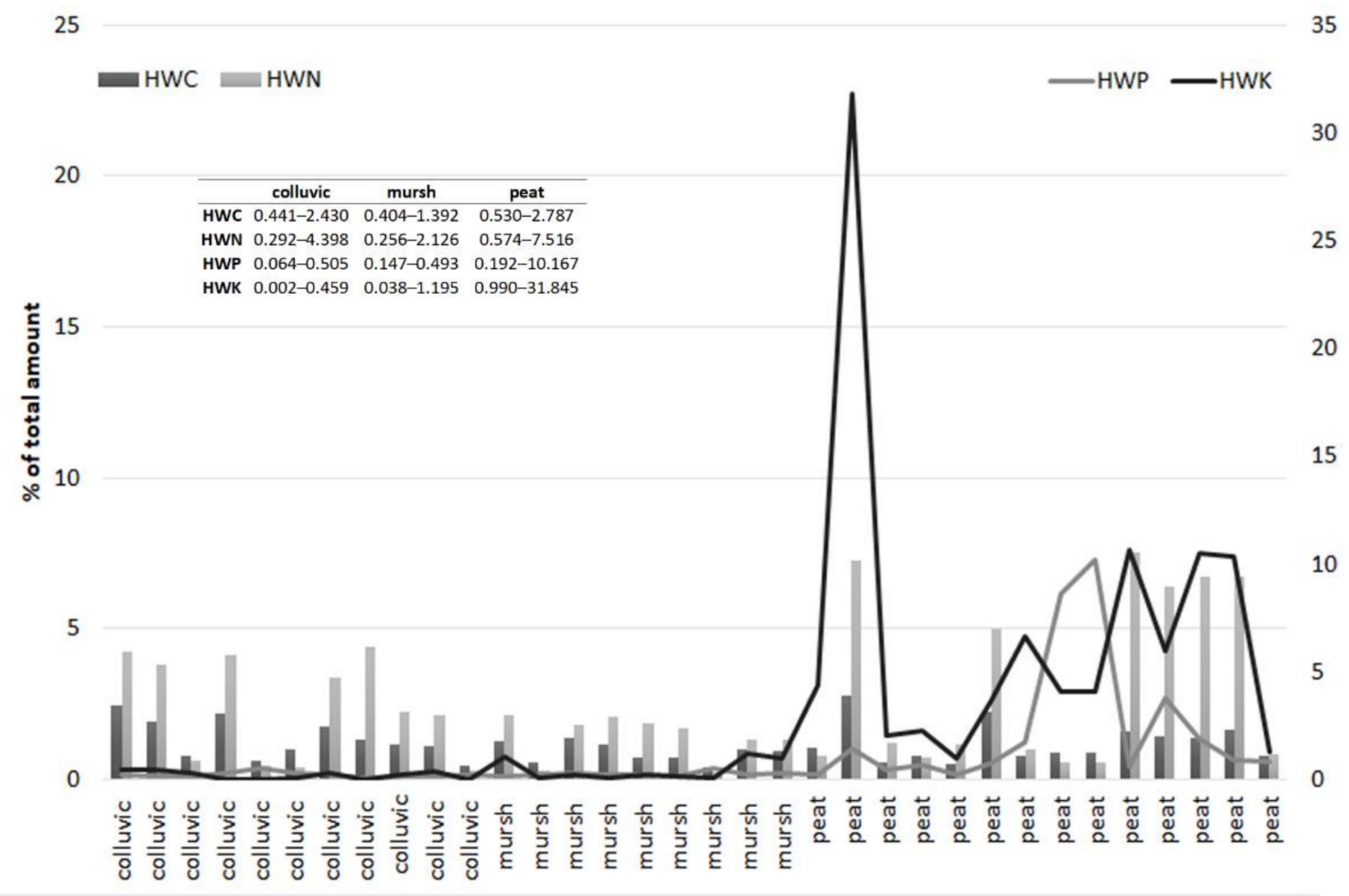

Figure 3. Share of hot-water C, N, P and K in the total content.
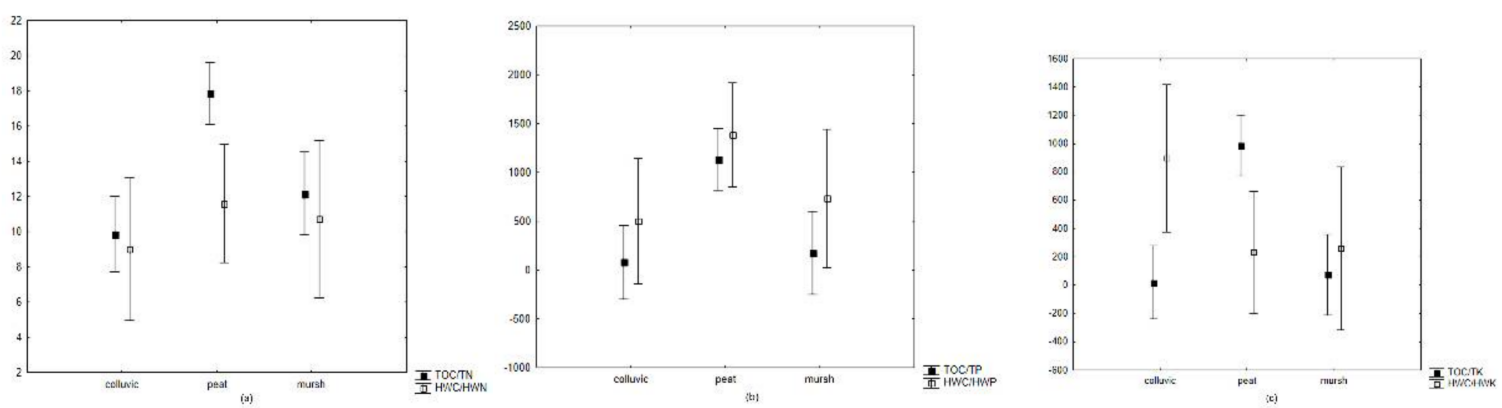

Figure 4. Average values of $(\mathbf{a}) \mathrm{C} / \mathrm{N},(\mathbf{b}) \mathrm{C} / \mathrm{P}$ and (c) $\mathrm{C} / \mathrm{K}$ ratios of total and labile compounds in colluvium, mursh and peats (vertical lines are the standard error).

\section{Discussion}

The response of labile organic matter to drainage and siltation supported our hypothesis that siltation of drained peatlands hampers the mineralization of the remaining peat layers. It was notable that siltation did not stop the mineralization but to some extent retarded the negative changes and loss of organic $C$. The results of our study are in line with the previous findings of the positive effect of peatland sanding [32]—covering peatlands with a layer of sand to enable agricultural use of peatlands.

The processes occurring in studied peatlands modified the carbon content in topsoil to such an extent that the original peat formations were classified as colluvium or silted 
mursh. The murshes and colluvium contained less TOC compared with the quantities in peats, which is related to both the aerobic nature of the mursh-forming process-i.e., intense mineralization of carbon from organic compounds-and the process of siltation of topsoil by the sediments eroding from the slope. The TN concentrations in topsoil murshes and colluvium were much lower than in peats, which is also typical for drained layers of peatlands [36]. The amounts of $\mathrm{C}$ and $\mathrm{N}$ and the TOC/TN ratios influence microbial activity and organic matter transformations [37-39]. The TOC/TN ratios narrower than 22-25 indicate the mineralization of organic nitrogen [40]. In all analyzed soil formations, the TOC/TN ratios were below 22, with higher values in peats, which indicates the ongoing process of mineralization of organic compounds. Similar results were also noted in other silted peatlands [29]. The TOC/TP ratio, similar to TOC/TN, is a reliable indicator of the soil organic matter transformation, as it provides information of the ongoing mineralization processes. In topsoil murshes and in colluvium, the TOC/TP ratio was lower than the value of 200-300, which is indicative of the mineralization [41]. In peats, the ratio was much higher, suggesting the stability of soil P $[10,11]$. Based on these two mentioned indicators of organic matter mineralization, we make the assumption that the topsoil is under the process of mineralization of organic matter, but peats are protected by siltation, and the mineralization is hampered. In addition to the TOC/TN and TOC/TP ratios, we also analyzed the TOC/TK ratio, having in mind that the main source of potassium is the weathering of soil minerals and that potassium stocks in peat are very low compared with those in mineral soil, whereas silted soil formations contain more potassium compounds than soils not affected by the erosional processes [42]. What we noticed is that the topsoil of peatlands had lower $\mathrm{C} / \mathrm{K}$ ratios than underlying peats, and this was related to the process of siltation.

The HWC concentrations in murshes and colluvium were lower than in the peats, which is typical for degraded layers of peatlands [9]. The values of HWC in peats were similar to the values reported by Kalisz et al. (2010) in peats and murshes or Mueller et al. (2007), but the values were lower than the values reported by Heller and Zeitz (2012). The labile OC fraction is more sensitive to disturbance than TOC [43]; therefore, processes other than drainage may result in the differences in HWC amounts. The HWC is correlated with TOC [3], and therefore the HWC concentrations in peats were the highest. However, it should also be stressed that the concentrations of HWC were lower in murshes than in peats, despite their both containing high amounts of organic carbon. This is common and related to the washing of labile compounds to lower parts of the soil profile. Furthermore, we also noted that the HWC concentration was lower in silted murshes than in the values reported for unsilted ones [23,44,45]. Therefore, we assumed that the concentration of HWC is not only related to TOC or washing but also to the siltation process. The HWN concentrations were also higher in peats than in murshes and colluvium but were lower than the concentrations reported by Heller and Zeitz (2012) in German drained peatlands. The HWN concentrations may vary widely, depending on the degree of peat decomposition, soil use and management practice $[8,14,46-51]$, suggesting that labile nitrogen release may be promoted when inorganic nitrogen is added to soil [9]. In the current study, no nitrogen fertilization occurred; therefore, the nitrogen release can be restricted to natural processes. The HWC/HWN ratios were the highest in peats and the lowest in colluvium, similar to the values of TOC/TN ratios. In other studies [9,51,52], the HWC/HWN ratios or soil DOC/DON ratios varied, and hardly any dependence was observed. The HWP and HWK contents, to the best of our knowledge, were not reported in the literature. What we noticed is that HWP and HWK in peats, unlike HWC and HWN, fluctuated within a wide range (Figure 3), which may be the effect of siltation of subsoil and washing out of labile $\mathrm{P}$ and $\mathrm{K}$. Higher concentrations of labile compounds in peat formations is a signal of higher biological activity and ongoing soil processes, and in case of drained peatlands, undoubtedly mineralization of organic matter occurs. However, taking into account the above calculated ratios, it can be assumed that the mineralization is hampered by the overlying silted topsoil. 
On the base of classification diagrams, we attempted to provide the quantitative criteria that enable the separation of peats from highly altered topsoil formations that were altered during drainage (mursh-forming process) and erosion (siltation). The quantitative criteria of organic matter transformation (mineralization or humification) that are wellknown in the soil scientific literature, include $C$, the $C / N$ ratio and the $C / P$ ratio. Based on the obtained results, we also noted that potassium is dependent on TOC changes; therefore, we also included the $\mathrm{C} / \mathrm{K}$ ratio into changes of the potential quantitative criteria. In Figure 5a-e, we present the classification of the analyzed soil formations, taking into account the results from the previous section.
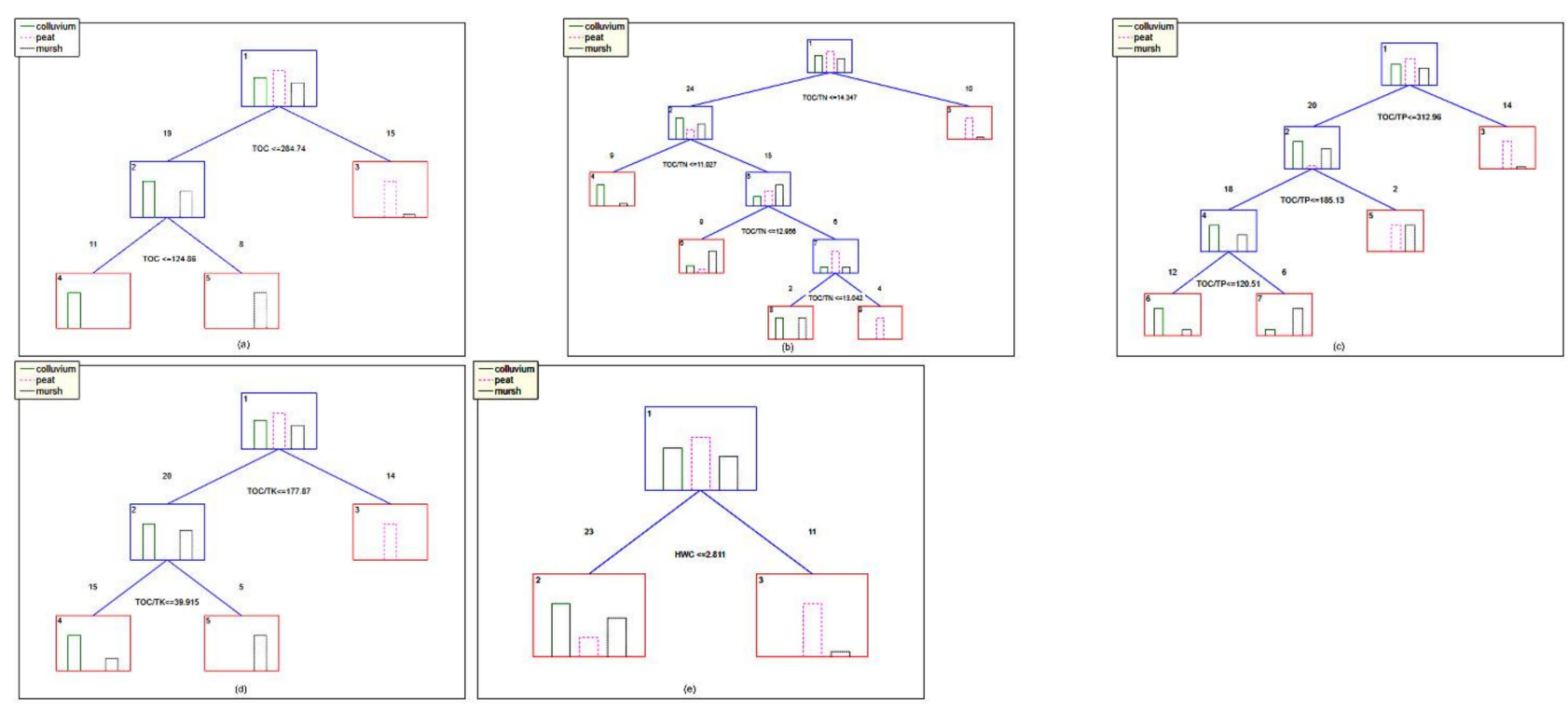

Figure 5. Classification diagrams of the topsoil and subsoil formations based on the indices of SOM changes: (a) TOC concentrations $\left(\mathrm{g} \mathrm{kg}^{-1}\right)$; (b) TOC/TN ratios; (c) TOC/TP ratios; (d) TOC/TK ratios; (e) HWC concentrations $\left(\mathrm{g} \mathrm{kg}^{-1}\right)$.

On the base of TOC (Figure 5a), we separated topsoil samples (colluvium and mursh) from underlying peats. The threshold value of $284.74 \mathrm{~g}$ of OC per $\mathrm{kg}$ of soil separates topsoil silted soil formations from underlying peats. The threshold of $124.86 \mathrm{~g}$ of OC per $\mathrm{kg}$ of soil enabled the separation of colluvium from murshes, i.e., highly silted topsoil from silted organic murshes. The TOC/TN ratio (Figure 5b) of 14.347 enabled the separation of ten soil formations - in this case, the separation of peats and murshes from other investigated soil formations. The TOC/TN ratio of 14 is relatively low for peats; however, we also noted that part of the peat samples had a TOC/TN ratio wider than 20 (Table S1). The value of 11 and 12.96 made it possible to distinguish subsequent groups that were a mixture of topsoil and subsoil formations. In the end, the TOC/TN value of 13 was the threshold for separation of topsoil and subsoil formations. The above is a confirmation that changes are taking place in the organic matter of all studied soil formations. The TOC/TN, however, did not make it possible to clearly distinguish and separate topsoil and subsoil formations, but higher TOC/TN—above 13 or 14-are typical for peats, not for silted topsoil.

The TOC/TP ratio (Figure 5c) enabled the separation of 14 topsoil formations (13 peats and 1 mursh sample) on the base of the threshold of 312.96. The value of 300 is the threshold value for ongoing mineralization [41]. A C/P ratio wider than 300 is indicative of relative phosphorous stabilization. Another differentiating threshold was the TOC/TP value of 185.13, which enabled the topsoil formations to be distinguished (TOC/TP lower than 185.13), while the value of 120 seems to distinguish colluvium from murshes (excluding two samples). This classification analysis supported our hypothesis that siltation hampered mineralization of organic matter compounds in peats and enables further separation of most of silted murshes from colluvium. 
Based on the TOC/TK ratio (Figure $5 \mathrm{~d}$ ) of 177.87, 16 peats were separated from 20 colluvic and mursh formations, and the TOC/TK value of 39.915 enabled the separation of murshes from colluvium. The TOC/TK turned out to be a fine indicator of the state of siltation of topsoil and separation of relatively unsilted soil organic formations (peats).

The concentration of $C$ in hot water extracts (Figure $5 e$ ) enabled the separation of 11 soil formations, mainly peats, from other studied soil formations. The threshold concentration was 2.81. The HWC turned out to be another fine indicator of the state of organic soils siltation. As it was mentioned above, based on the HWC concentrations in silted or unsilted murshes (current study and previous studies of Kalisz) and classification diagrams in Figure 5, lower values of HWC in topsoil are related not only to TOC or washing but also to the siltation process. Topsoil can be regarded as less biologically active, having less oxygen when being silted and therefore playing a role that protects underlying peats against oxidation.

The calculated HWC/HWN or $\mathrm{HWC} / \mathrm{HWP}$ or $\mathrm{HWC} / \mathrm{HWK}$ ratios did not allow any classification that would enable soil formations to be distinguished. Nevertheless, the concentrations of labile forms of nutrients should be monitored, and the changes in concentrations should be tracked in the studies of drained peat soils. In the short-term, the relation between dissolved organic compounds and soil organic compounds is not significant [50], but the relationship is significant from a longer-term perspective.

\section{Conclusions}

The concentrations of hot-water (labile) C, N, P and K were generally low in all analyzed soil samples. The HWC concentrations were higher in peats than in silted topsoil and also turned out to be fine indicators of the state of organic soils siltation. Based on statistical analyses, an HWC concentration of $2.8 \mathrm{~g} \mathrm{k}^{-1}$ enabled the separation of silted topsoil (HWC < 2.8) from relatively unsilted subsoil peats. Noteworthy is the high proportion of HWN in relation to total nitrogen for all studied soil samples as well as for HWP and HWK in relation to total $\mathrm{P}$ and total $\mathrm{K}$ in peat samples. Higher concentration of labile compounds in peats is a signal of higher biological activity and ongoing soil processes and, in the case of drained peatlands, mineralization of organic matter. The well-known indicators of soil organic matter changes, i.e., TOC/TP and TOC/TN ratios, supported our hypothesis that siltation hampered mineralization of organic matter-in topsoil, both indicators were lower than in peats, suggesting diminished mineralization. The TOC/TK ratio turned out to be another fine indicator of the state of siltation of topsoil, which enabled the separation of relatively unsilted soil organic formations (peats) from silted topsoil (on the base of value of 177). The TOC/TK ratio should be regarded as a case study and verified in further studies. Considering the calculated ratios, it can be assumed that the mineralization of peat layers is hampered by the above lying silted topsoil. Topsoil can be regarded as less biologically active, having less oxygen, and therefore conserving underlying peats against oxidation.

Supplementary Materials: The following are available online at https:/ / www.mdpi.com/article/10 $.3390 /$ su13158240/s1, Table S1: The amounts (in $\mathrm{g} \mathrm{kg}^{-1}$ ) of total and labile C, N, P and K, as well as calculated ratios of $\mathrm{C} / \mathrm{N}, \mathrm{C} / \mathrm{P}$ and $\mathrm{C} / \mathrm{K}$ in investigated soil formations.

Author Contributions: Conceptualization, S.S. and B.K.; methodology, S.S., B.K. and P.U.; validation, S.S. and B.K.; investigation, S.S., B.K., P.U. and M.O.; writing-original draft preparation, S.S., B.K., P.U. and M.O.; funding acquisition, S.S. All authors have read and agreed to the published version of the manuscript.

Funding: The results presented in this paper were obtained as a part of comprehensive study financed by the University of Warmia and Mazury in Olsztyn, Faculty of Agriculture and Forestry, Department of Soil Science and Microbiology (grant No. 30.610.005-110) and by a project supported by the Minister of Science and Higher Education under the auspices of a program entitled "Regional Initiative of Excellence" for the years 2019-2022, Project No. 010/RID/2018/19 (amount of funding PLN 12,000,000). 
Institutional Review Board Statement: Not applicable.

Informed Consent Statement: Not applicable.

Data Availability Statement: The data presented in this study are available in the corresponding references.

Conflicts of Interest: The authors declare no conflict of interest. The funders had no role in the design of the study; in the collection, analyses, or interpretation of data; in the writing of the manuscript; or in the decision to publish the results.

\section{References}

1. Blazier, M..; Liechty, H. Assessment of Labile Organic Carbon in Soil Using Sequential Fumigation Incubation Procedures. Jove-J. Vis. Exp. 2016, 8. [CrossRef]

2. McLauchlan, K.K.; Hobbie, S.E. Comparison of labile soil organic matter fractionation techniques. Soil Sci. Soc. Am. J. 2004, 68, 1616-1625. [CrossRef]

3. Kalisz, B.; Lachacz, A.; Glazewski, R. Effects of peat drainage on labile organic carbon and water repellency in NE Poland. Turk. J. Agric. For. 2015, 39, 20-27. [CrossRef]

4. Zhang, X.; Li, Z.; Nie, X.; Huang, M.; Wang, D.; Xiao, H.; Liu, C.; Peng, H.; Jiang, J.; Zeng, G. The role of dissolved organic matter in soil organic carbon stability under water erosion. Ecol. Indic. 2019, 102, 724-733. [CrossRef]

5. Zhang, L.; Chen, X.; Xu, Y.; Jin, M.; Ye, X.; Gao, H.; Chu, W.; Mao, J.; Thompson, M.L. Soil labile organic carbon fractions and soil enzyme activities after 10 years of continuous fertilization and wheat residue incorporation. Sci. Rep. 2020, 10, 11318. [CrossRef] [PubMed]

6. Kalbitz, K.; Solinger, S.; Park, J.H.; Michalzik, B.; Matzner, E. Controls on the dynamics of dissolved organic matter in soils: A review. Soil Sci. 2000, 165, 277-304. [CrossRef]

7. Landgraf, D.; Leinweber, P.; Makeschin, F. Cold and hot water-extractable organic matter as indicators of litter decomposition in forest soils. J. Plant Nutr. Soil Sci. 2006, 169, 76-82. [CrossRef]

8. Ghani, A.; Sarathchandra, U.; Ledgard, S.; Dexter, M.; Lindsey, S. Microbial decomposition of leached or extracted dissolved organic carbon and nitrogen from pasture soils. Biol. Fertil. Soils 2013, 49, 747-755. [CrossRef]

9. Kalbitz, K.; Geyer, S. Different effects of peat degradation on dissolved organic carbon and nitrogen. Org. Geochem. 2002, 33, 319-326. [CrossRef]

10. McDowell, W.H.; Zsolnay, A.; Aitkenhead-Peterson, J.A.; Gregorich, E.G.; Jones, D.L.; Joedemann, D.; Kalbitz, K.; Marschner, B.; Schwesig, D. A comparison of methods to determine the biodegradable dissolved organic carbon from different terrestrial sources. Soil Biol. Biochem. 2006, 38, 1933-1942. [CrossRef]

11. Simmonds, B.; McDowell, R.W.; Condron, L.M.; Cox, N. Can phosphorus fertilizers sparingly soluble in water decrease phosphorus leaching loss from an acid peat soil? Soil Use Manag. 2016, 32, 322-328. [CrossRef]

12. Cao, L.; Song, J.M.; Wang, Q.D.; Li, X.G.; Yuan, H.M.; Li, N.; Duan, L.Q. Characterization of Labile Organic Carbon in Different Coastal Wetland Soils of Laizhou Bay, Bohai Sea. Wetlands 2017, 37, 163-175. [CrossRef]

13. Duval, M.E.; Galantini, J.A.; Martinez, J.M.; Limbozzi, F. Labile soil organic carbon for assessing soil quality: Influence of management practices and edaphic conditions. Catena 2018, 171, 316-326. [CrossRef]

14. Muciaddas, B.; Lewis, T.; Esfandbod, M.; Chen, C.R. Responses of labile soil organic carbon and nitrogen pools to long-term prescribed burning regimes in a wet sclerophyll forest of southeast Queensland, Australia. Sci. Total Environ. 2019, 647, 110-120. [CrossRef] [PubMed]

15. Norberg, L.; Bergiund, O.; Bergiund, K. Impact of drainage and soil properties on carbon dioxide emissions from intact cores of cultivated peat soils. Mires Peat 2018, 21, 14. [CrossRef]

16. Bojko, O.; Kabala, C.; Mendyk, L.; Markiewicz, M.; Pagacz-Kostrzewa, M.; Glina, B. Labile and stabile soil organic carbon fractions in surface horizons of mountain soils-Relationships with vegetation and altitude. J. Mt. Sci. 2017, 14, 2391-2405. [CrossRef]

17. Kaiser, K.; Kalbitz, K. Cycling downwards-Dissolved organic matter in soils. Soil Biol. Biochem. 2012, 52, 29-32. [CrossRef]

18. Armstrong, A.; Holden, J.; Kay, P.; Francis, B.; Foulger, M.; Gledhill, S.; McDonald, A.T.; Walker, A. The impact of peatland drain-blocking on dissolved organic carbon loss and discolouration of water; results from a national survey. J. Hydrol. 2010, 381, 112-120. [CrossRef]

19. Fenner, N.; Williams, R.; Toberman, H.; Hughes, S.; Reynolds, B.; Freeman, C. Decomposition 'hotspots' in a rewetted peatland: Implications for water quality and carbon cycling. Hydrobiologia 2011, 674, 51-66. [CrossRef]

20. Limpens, J.; Berendse, F.; Blodau, C.; Canadell, J.G.; Freeman, C.; Holden, J.; Roulet, N.; Rydin, H.; Schaepman-Strub, G. Peatlands and the carbon cycle: From local processes to global implications-a synthesis. Biogeosciences 2008, 5, 1475-1491. [CrossRef]

21. Page, S.E.a.B.A.J. Peatlands and Global Change: Response and Resilience. Annu. Rev. Environ. Resour. 2016, 41, 35-57. [CrossRef]

22. Glina, B.; Gajewski, P.; Kaczmarek, Z.; Owczarzak, W.; Rybczynski, P. Current state of peatland soils as an effect of long-term drainage-Preliminary results of peatland ecosystems investigation in the Grojecka Valley (central Poland). Soil Sci. Annu. 2016, 67, 3-9. [CrossRef] 
23. Kalisz, B.; Lachacz, A.; Glazewski, R. Transformation of some organic matter components in organic soils exposed to drainage. Turk. J. Agric. For. 2010, 34, 245-256. [CrossRef]

24. Lachacz, A.; Nitkiewicz, M.; Kalisz, B. Water repellency of post-boggy soils with a various content of organic matter. Biologia 2009, 64, 634-638. [CrossRef]

25. Mendyk, L.; Hulisz, P.; Kusza, G.; Switoniak, M.; Gersztyn, L.; Kalisz, B. Sediment origin and pedogenesis in the former mill pond basin of Turznice (north-central Poland) based on magnetic susceptibility measurements. Bull. Geogr. Phys. Geogr. Ser. 2016, 11, 55-69. [CrossRef]

26. Banasik, K.; Hejduk, L.; Krajewski, A.; Wasilewicz, M. The intensity of siltation of a small reservoir in Poland and its relationship to environmental changes. Catena 2021, 204, 12. [CrossRef]

27. Auerswald, K.; Geist, J. Extent and causes of siltation in a headwater stream bed: Catchment soil erosion is less important than internal stream processes. Land Degrad. Dev. 2018, 29, 737-748. [CrossRef]

28. Kovacs, A.S.; Fulop, B.; Honti, M. Detection of hot spots of soil erosion and reservoir siltation in ungauged Mediterranean catchments. Energy Procedia 2012, 18, 934-943. [CrossRef]

29. Smolczynski, S.; Kalisz, B.; Orzechowski, M. Sequestration of Humus Compounds in Soils of Northeastern Poland. Pol. J. Environ. Stud. 2011, 20, 755-762.

30. Smolczynski, S.; Orzechowski, M.; Kalisz, B. Distribution of elements in soil catenas developed in ice-dammed lake and in morainic landscapes in ne poland. J. Elem. 2015, 20, 417-434. [CrossRef]

31. Sowinski, P.; Orzechowski, M.; Smolczynski, S.; Kalisz, B. Particle-size distribution in soils in various ground moraine catenas in the masurian lakeland. Pol. J. Soil Sci. 2015, 48, 139-150. [CrossRef]

32. Zakharova, O.A.; Musaev, F.A.; Kucher, D.E.; Vinogradov, D.V.; Ushakov, R.N. Sanding of drained peatlands. BIO Web Conf. 2020, 17, 00089. [CrossRef]

33. Zaidel'man, F.R.; Kozhevin, P.A.; Shvarov, A.P.; Pavlova, E.B.; Gorlenko, M.V. The effect of different sanding methods on the biological activity and gas regime of drained peat soils. Eurasian Soil Sci. 2001, 34, 207-216.

34. Smólczyński, S.; Orzechowski, M. Soils of ecotone zones of meltwater basins and slopes in a young glacial landscape of the Mazurian Lakeland. Soil Sci. Annu. 2010, 61, 217-226.

35. Smólczyński, S.; Orzechowski, M. Sorptive properties of upper-silted organic soils in various landscapes of north-eastern Poland. Pol. J. Soil Sci. 2010, 43, 129-140.

36. Thaysen, E.M.; Reinsch, S.; Larsen, K.S.; Ambus, P. Decrease in heathland soil labile organic carbon under future atmospheric and climatic conditions. Biogeochemistry 2017, 133, 17-36. [CrossRef]

37. Smith, H.J.; Foster, R.A.; McKnight, D.M.; Lisle, J.T.; Littmann, S.; Kuypers, M.M.M.; Foreman, C.M. Microbial formation of labile organic carbon in Antarctic glacial environments. Nat. Geosci. 2017, 10, 356. [CrossRef]

38. Glina, B.; Bogacz, A.; Wozniczka, P. Nitrogen mineralization in forestry-drained peatland soils in the Stolowe Mountains National Park (Central Sudetes Mts). Soil Sci. Annu. 2016, 67, 64-72. [CrossRef]

39. Quideau, S.A.; Norris, C.E.; Rees, F.; Dyck, M.; Samadi, N.; Oh, S.W. Carbon, nitrogen, and phosphorus release from peat and forest floor-based cover soils used during oil sands reclamation. Can. J. Soil Sci. 2017, 97, 757-768. [CrossRef]

40. Zhao, S.X.; Ta, N.; Li, Z.H.; Yang, Y.; Zhang, X.; Liu, D.; Zhang, A.; Wang, X.D. Varying pyrolysis temperature impacts application effects of biochar on soil labile organic carbon and humic fractions. Appl. Soil Ecol. 2018, 123, 484-493. [CrossRef]

41. Stutter, M.I.; Shand, C.A.; George, T.S.; Blackwell, M.S.A.; Dixon, L.; Bol, R.; MacKay, R.L.; Richardson, A.E.; Condron, L.M.; Haygarth, P.M. Land use and soil factors affecting accumulation of phosphorus species in temperate soils. Geoderma 2015, 257, 29-39. [CrossRef]

42. Orzechowski, M.; Smolczynski, S.; Kalisz, B.; Dlugosz, J.; Sowinski, P. Chemical and mineralogical composition of the holocene soil sediments in north-eastern poland. J. Elem. 2020, 25, 471-485. [CrossRef]

43. Roper, M.M.; Gupta, V.V.S.R.; Murphy, D.V. Tillage practices altered labile soil organic carbon and microbial function without affecting crop yields. Aust. J. Soil Res. 2010, 48, 274-285. [CrossRef]

44. Smolczynski, S.; Orzechowski, M.; Kalisz, B.; Krupinski, K. Selected properties of reclaimed mine soils in the area of a former gravel mine in north-eastern Poland. Soil Sci. Annu. 2020, 71, 66-75. [CrossRef]

45. Kalisz, B.; Łachacz, A.; Klasa, A.; Smólczyński, S.; Orzechowski, M.; Sowiński, P. Water permeability of soils amended with sewage sludge on short-rotation plantations in Europe. Pol. J. Soil Sci. 2015, 48, 131-137. [CrossRef]

46. Mueller, L.; Wirth, S.; Schulz, E.; Behrendt, A.; Hoehn, A.; Schindler, U. Implications of soil substrate and land use for properties of fen soils in North-East Germany Part I: Basic soil conditions, chemical and biological properties of topsoils. Arch. Agron. Soil Sci. 2007, 53, 113-126. [CrossRef]

47. Hussain, M.Z.; Robertson, G.P.; Basso, B.; Hamilton, S.K. Leaching losses of dissolved organic carbon and nitrogen from agricultural soils in the upper US Midwest. Sci. Total Environ. 2020, 734, 139379. [CrossRef] [PubMed]

48. Heinz, M.; Zak, D. Storage effects on quantity and composition of dissolved organic carbon and nitrogen of lake water, leaf leachate and peat soil water. Water Res. 2018, 130, 98-104. [CrossRef] [PubMed]

49. Li, J.; Wen, Y.C.; Li, X.H.; Li, Y.T.; Yang, X.D.; Lin, Z.; Song, Z.Z.; Cooper, J.M.; Zhao, B.Q. Soil labile organic carbon fractions and soil organic carbon stocks as affected by long-term organic and mineral fertilization regimes in the North China Plain. Soil Tillage Res. 2018, 175, 281-290. [CrossRef] 
50. Zhou, W.-J.; Sha, L.-Q.; Schaefer, D.A.; Zhang, Y.-P.; Song, Q.-H.; Tan, Z.-H.; Deng, Y.; Deng, X.-B.; Guan, H.-L. Direct effects of litter decomposition on soil dissolved organic carbon and nitrogen in a tropical rainforest. Soil Biol. Biochem. 2015, 81, 255-258. [CrossRef]

51. Heller, C.; Zeitz, J. Stability of soil organic matter in two northeastern German fen soils: The influence of site and soil development. J. Soils Sediments 2012, 12, 1231-1240. [CrossRef]

52. Williams, B.L.; Silcock, D.J. Impact of NH4NO3 on microbial biomass C and N and extractable DOM in raised bog peat beneath Sphagnum capillifolium and S-recurvum. Biogeochemistry 2000, 49, 259-276. [CrossRef] 